\title{
RESEÑAS BREVES
}

Juan Carlos Moreno Cabrera, La lingüistica teórico-tipológica. Gredos, Madrid, 1995; 194 pp.

Llena este libro un gran vacío en la bibliografía en español, apenas cubierto con algunas traducciones: la introducción a los estudios tipológicos. El interés es mayor si se considera el acento puesto en los estudios tipológicos europeos. De hecho, es paradójico que más de una vez sean los proyectos en tipología del Viejo Continente los menos conocidos, cuando la mayor parte de ellos surgieron y se desarrollaron ahí.

El libro está dividido en cinco capítulos. En el primero se establecen las herramientas conceptuales y terminológicas, lo bastante amplias como para plantear las preguntas esenciales de la investigación tipológica y para formular parámetros básicos para describir los diferentes proyectos. La argumentación se sustenta en dos principios: el de la opacidad (las lenguas no explicitan completamente todas sus propiedades lingüísticas) y el de la perspectiva (propiedades opacas en una lengua pueden ser transparentes en otra). El segundo capítulo está dedicado a los principios teóricos y empíricos. En la parte teórica se presenta una propuesta basada en la gramática de Montague; entre lo más llamativo de las páginas dedicadas a los problemas empíricos está lo referente al muestreo lingüístico. Es posible que el lector hubiera querido algo más de detalle en la exposición de este capítulo. Enlaza este segundo con un tercero dedicado a las partes del discurso; hubiera sido muy interesante desarrollar en este o en otros capítulos algunos problemas gramaticales que ilustraran más a fondo el modo de proceder tipológico.

Uno de los capítulos más útiles es el cuarto, en el que se presentan, describen y evalúan (esto último es meritorio y muy de agradecer) los proyectos tipológicos de Stanford, San Petersburgo, UNITYP, RIVALC y EUROTYP. La información sobre las bases conceptuales de los proyectos, los comentarios bibliográficos y la descripción de las principales líneas de trabajo son buena guía para quien desee orientarse en este complejo mundo. En cuanto al último capítulo, en que se examinan 
algunas consecuencias cognitivas de esta clase de lingüística, aunque es interesante, no se puede evitar cierta sensación por parte del lector de que queda un poco al margen de la exposición principal del volumen. Cierra el libro una útil bibliografía de tipología, universales y clasificación de lenguas. (P. Martín Butragueño)

Jamile Trueba Lawland, El arte epistolar en el Renacimiento español. Tamesis, Madrid, 1996; 162 pp.

Quien no ha incursionado en la preceptiva del dictamen tiene aquí una bibliografía rica en información, lo que indica que la investigación se hizo a conciencia; pero quien esté familiarizado con el tema poco encontrará de nuevo. Bajo título tan sugerente, se acumula una serie de fichas bien documentadas pero no expurgadas: se repiten datos hasta la monotonía, y lo que es valioso para una exposición armónica -diálogo con los textos, la economía que proporcionan las referencias cruzadas- se aísla en apéndices, uno de los cuales ("Relación de artes y formularios epistolares españoles del siglo xvı"), es recapitulación de lo que se entendió bien en el texto.

Quince páginas se destinan a la historia del género; podrían haberse incluido ahí las cuatro dedicadas a la Edad Media, capítulo cuya brevedad no tiene justificación muy sólida: que el "arte dictaminal no forma parte del sistema epistolar de los humanistas” (p. 15), con lo que, supongo, se refiere a las normas rígidas de la correspondencia medieval frente al estilo ensayístico de las cartas que se escribieron en el Renacimiento.

Prescindiendo de los capítulos tercero a quinto, que tratan sobre el arte epistolar renacentista, los tratados de Erasmo y Vives (es de preguntar si el de éste puede calificarse de español), lo que ampara el título del libro comienza realmente en el capítulo sexto ("Otros tratados españoles del siglo Xvı”); le siguen un análisis descriptivo (aunque se intenta poner en práctica las teorías de Hermógenes) de las Epistolas familiares de Guevara, otro muy breve sobre algunas cartas de Santa Teresa y los apéndices mencionados arriba.

Hay problemas con el español, nada extraño cuando el trabajo original se escribió -o se pensó- en otra lengua. Puesto que el contenido del libro fue originalmente una tesis que se defendió en la Universidad de Michigan, es probable que el texto se haya presentado en inglés; no de otra manera se explican frases y léxico extraños repartidos en todo el libro, que hubieran necesitado un corrector de estilo, como, por ejemplo, "si miramos el tratado", "contiene omisiones"; "los temas de las cartas oficiales son de índole oficial"; "Petrarca ofrece a sus correspondientes" (corresponsales); "no puedo imaginar por qué el copista los suprime, ya que existen varias posibilidades de por qué lo hace"; o la extraña explica- 